\title{
Understanding project-based learning in Second Life with a pedagogy, training, and assessment trio
}

\author{
Leslie Jarmon $^{\mathrm{a} *}$, Tomoko Traphagan $^{\mathrm{b}}$ and Michael Mayrath ${ }^{\mathrm{b}}$ \\ ${ }^{a}$ Office of Graduate Studies, University of Texas at Austin, Austin, Texas, USA; ${ }^{b}$ Division of \\ Instructional Innovation and Assessment, The University of Texas at Austin, Austin, Texas, USA
}

(Received 27 May 2008; final version received 18 June 2008)

This paper presents an empirical study of how Second Life (SL) was utilized for a highly successful project-based graduate interdisciplinary communication course. Researchers found that an integrated threefold approach emphasizing project-based pedagogy, technical training and support, and assessment/research was effective in cultivating and understanding learning in SL. Based on research findings, a projectbased application of SL that fully accommodates student experiential learning is recommended. It is suggested that teachers who are new To Whom It May Concern: SL and are preparing to "take the plunge" adopt a systematic team approach to integrate this trio of components. The students participating in this study formed an interdisciplinary team for their required SL project in which they chose to initiate a collaboration with the Basic Initiative and a group of architecture students to create a virtual presence for two green, sustainable, urban housing designs called the Alley Flats. Preliminary survey results suggest that the use of SL substantially enhanced the quality and experiences of student learning. Specific areas for improvement in future use are also identified.

\section{Comprendre l'Apprentissage basé sur les projets dans le cadre de Second Life avec le trio Pédagogie-Formation et Evaluation.}

Le présent article présente une étude empirique sur la façon dont Second Life (SL) a été utilisé dans le cadre d'un cours de communication interdisciplinaire avancé fondé sur la réalisation de projets, cours qui a connu un grand succès. Les chercheurs ont trouvé qu'une approche intégrée en trois points, mettant l'accent sur la pédagogie des projets, la formation et le soutien techniques et l'évaluation/recherche se révélait efficace pour cultiver et comprendre l'apprentissage dans le cadre de SL. Les résultats de la recherche conduisent à recommander une application de Second Life fondée sur les projets, application qui prend pleinement en compte l'apprentissage des étudiants par l'expérience. On suggère que les professeurs qui sont nouveaux dans SL et qui se préparent à "faire le plongeon", adoptent de façon systématique un mode d'approche en équipe, ceci pour intégrer ce trio de composantes. Les étudiants qui ont participé à cette étude formaient une équipe interdisciplinaire pour le projet SL qu'ils devaient réaliser et dans ce cadre, ils ont choisi de mettre en route une collaboration avec "The Basic Initiative" et un groupe d'étudiants d'architecture dans le but de créer une présence virtuelle pour concevoir deux projets d'habitat urbain vert et gérable appelés les Appartements de l'Allée. Une enquête préliminaire permet de penser que l'utilisation de SL a fortement amélioré le vécu et la qualité de l'apprentissage chez les étudiants. On a également identifié des zones spécifiques pour les améliorations à apporter pour des usages futurs.

\footnotetext{
*Corresponding author. Email: LJarmon@mail.utexas.edu
} 
Verstehen Projektbasierten Lernens in Second Life im Kontext von Pädagogik,
Training und Beurteilung Mit diesem Beitrag wird eine empirische Studie präsentiert, die berichtet wie Second Life (SL) sehr erfolgreich in einem projektorientierten und interdisziplinären Kommunikationskurs für Studenten genutzt worden ist. Unsere Untersuchung ergab, dass ein integrierter dreistufiger Ansatz - projektbasierte Pädagogik, technische Ausbildung und Unterstützung, sowie Beurteilung - zum besseren Verständnis über das Lernen mit Hilfe von SL führte. Auf Grundlage von Forschungsbergebnissen wird empfohlen, dass einer projektbasierten Ausarbeitung wird auf Erfahrung beruhendes Lernen zur Anwendung von SL empfohlen. Es wird geraten, dass Lehrer, die noch keine Erfahrung mit SL haben, einen systematischen Teamansatz übernehmen, um diese drei Bestandteile zu integrieren. Die Studenten, die an dieser Studie teilnahmen, bildeten ein interdisziplinäres Team, damit ihr angestrebtes SL Projekt, worin sie eine Kollaboration mit der Grundinitiative und einer Gruppe von Architekturstudenten initiieren wollten, eine virtuelle Gegenwart für zwei "the Alley Flats" genannte grüne, nachhaltige, städtische Unterbringungspläne schaffe. In vorläufigen Umfrageergebnissen wird festgestellt, dass die Verwendung von SL die Qualität der Arbeit und die Möglichkeit der Erfahrungen der Studenten zu lernen, beträchtlich verbesserte. Bestimmte Bereiche zur Verbesserung zukünftiger Verwendungen wurden ebenfalls identifiziert.

\section{Comprender el aprendizaje basado en proyectos dentro de Second Life con el trio Pedagogía, Formación/Evaluación.}

Este artículo presenta un estudio empírico sobre la manera en que Second Life fue utilizado para un curso de comunicación avanzado, interdisciplinario y altamente exitoso basado en proyectos. Los investigadores han descubierto que un abordaje integrado triple con énfasis en la pedagogía basada en proyectos, en la formación y el soporte técnico y en evaluación/investigación, resultaba efectivo para cultivar y comprender el aprendizaje en SL. Basandose en los resultados de la investigación, se recomienda una aplicación de Second Life basada en proyectos integrando completamente la experiencia de aprendizaje por parte de los estudiantes. Nuestra sugestión es que los profesores que son nuevos en SL y listos a zambullirse, adopten una metodología de trabajo en equipo para integrar este trio de componentes. Los estudiantes que participaron en este proyecto formaban equipos interdisciplinarios para sus proyectos SL y decidieron de iniciar una colaboración con "The Basic Initiative" y un grupo de estudiantes de arquitectura de modo a crear una presencia virtual para dos diseños de viviendas urbanas verdes y sostenibles llamadas Los Apartamentos de la Alameda. Los resultados de las encuestas preliminarias indican que el uso de SL realzó fuertemente la calidad y la vivencia del aprendizaje estudiantil. Se identificó también sectores específicos para futuras mejoras.

Keywords: virtual worlds; project-based learning; Second Life; assessment; experiential learning; interdisciplinary learning

\section{Introduction}

Gartner, Inc. (2007), a technology-related research and consulting firm, estimates that by $2011,80 \%$ of active Internet users, including Fortune 500 enterprises, will have a "second life" in some form of 3-D virtual world environment, and these virtual worlds are expected to have a large impact on teaching and learning in the very near future. Yet there are few empirical studies that inform instructional design and practices in 3-D virtual worlds. This paper presents how we utilized Second Life (SL) for a highly successful project-based graduate interdisciplinary communication course offered at the University of Texas at Austin in 2007.

We first summarize literature that suggests that the use of SL is suited for experiential learning in interdisciplinary communication. We then delineate a systematic team approach and how it facilitated the integration of the trio of key components. Next, we 
present our preliminary results that indicate strong experiential learning benefits from using SL to facilitate graduate students learning of interdisciplinary communication strategies. Finally, we conclude that an integrated threefold approach emphasizing projectbased pedagogy, technical training and support, and assessment/research was effective in cultivating and understanding learning with SL. We recommend a project-based application of SL to fully accommodate student experiential learning, and we suggest a systematic team approach to assist teachers who are new to SL as they prepare to "take the plunge."

\section{Background}

Virtual 3-D worlds such as SL are rapidly being accepted and used in instructional settings. Indeed, the New Media Consortium and the EDUCAUSE Learning Initiative (2007) identified virtual worlds as an emerging technology that is likely to have a large impact on teaching and learning. The presence of SL in higher education is already visible in various courses (e.g. project management; Figure 1), team learning activities, and real collaborations among individuals.

Potential instructional benefits of 3-D virtual worlds include those common to games as well as virtual worlds, such as accommodating learning preferences of Net Generation students, enhancing student motivation and engagement, providing opportunities for social

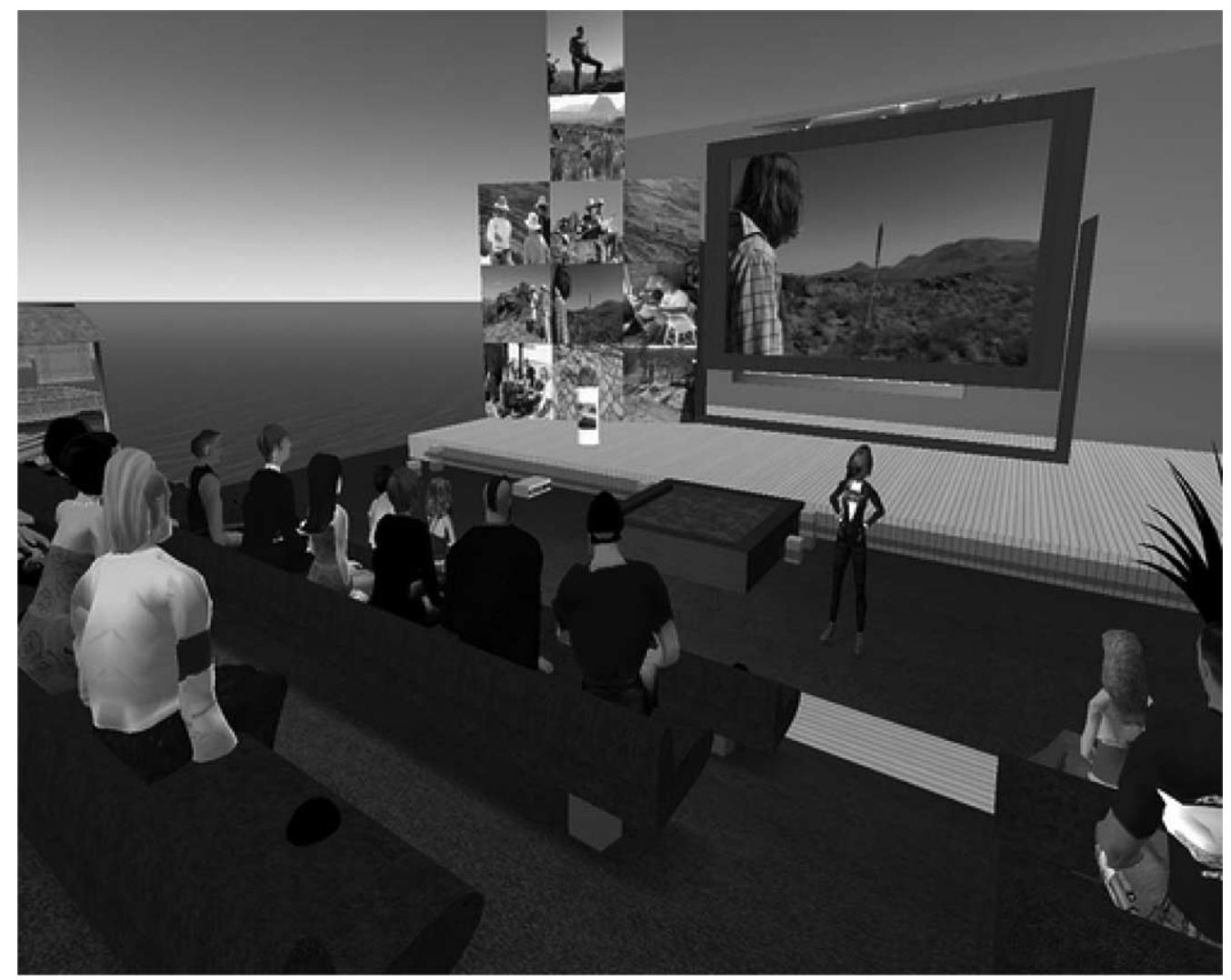

Figure 1. A project management class in Second Life. 
interaction, facilitating collaboration, increasing a sense of shared presence, dissolving social boundaries, and allowing for exploration, creation, and interaction within a media rich environment (Craig, 2007; Dede, Clarke, Ketelhut, Nelson, \& Bowman, 2005; FitzGerald, 2007; Gee, 2003; Kirriemuir \& McFarlane, 2003; Lamb, 2006; McGee, 2007; Prensky, 2006). The lack of a predefined structure for how to use 3-D virtual worlds in education underscores the necessity for comprehensive instructional design planning in order to facilitate learning in such environments (Mayrath, Sanchez, Traphagan, Heikes, \& Trivedi, 2007; Sanchez, 2007). Few empirical studies document learning within virtual worlds; thus, our study explores the nature and process of learning in SL within the context of a projectbased interdisciplinary communication course design.

Existing literature in three different fields suggests that SL could facilitate learning about interdisciplinary communication. First, studies in computer mediated communication (CMC) find that diverse people interacting via the Internet are more likely to experience positive contact and a shared understanding due to the elimination of geographical barriers, reduction in social anxiety promoting ease of disclosure, and control over the environment (Amichai-Hamburger \& McKenna, 2006; Soukup, 2004). Similarly, Steinkuehler and Williams (2006) found that interacting within virtual worlds not only helps people build communities but also exposes them to a "diversity of world views" through the development of these virtual social relationships.

Second, research on animated pedagogical agents has shown that agents can increase motivation and learning due to a perceived social relationship between the learner and the agent (Atkinson, Mayer, \& Merrill, 2005; Kim and Baylor, 2006; Mayer, Sobko, \& Mautone, 2003; Moreno, Mayern, Spires, \& Lester, 2001).

Third, literature on experiential learning suggests that elements of the communication in SL may serve student learning in new ways. To foster experiential learning, the activities designed for the course in this study take advantage of the 3-D virtual worlds' affordances for engagement in social interactions with people from various fields across geographical distances. Performative strategies for experiential learning, including narrative and improvisation (Bateson, 1993; Taussig, 1993), are being used in SL. Role play, improvisation, and other action-based activities are used to foster experiential learning in training emergency personnel and nurses (e.g. Ann Meyers Medical Center; Figure 2), for interacting with reflexive architecture (Brouchoud, 2006, and see Akrich, 1992, on "technical objects"), and for learning to play virtual musical instruments with the avatar orchestra metaverse (AOM) (Figure 3).

This brief survey of literature suggests that the use of SL may be suited for experiential learning and therefore for use in a project-based interdisciplinary communication course where students must demonstrate their learning by creating a virtual presence.

\section{A systematic team approach: the trio}

Our research team was a joint effort at UT-Austin of The Graduate School and the Division of Instructional Innovation and Assessment. Very early in the process, we decided to take a systematic team approach to insure that our pilot integrated the assessment/research and training components into the core instructional design to complement but not interfere with the class. Early and lengthy brainstorming sessions with the whole team ensured comprehensive and effective coordination of the trio of elements: pedagogy, training, and assessment. We collaborated in all key processes including instructional design for SL activities, implementation of training and technical support, and creating assessment surveys and focus group protocols. 


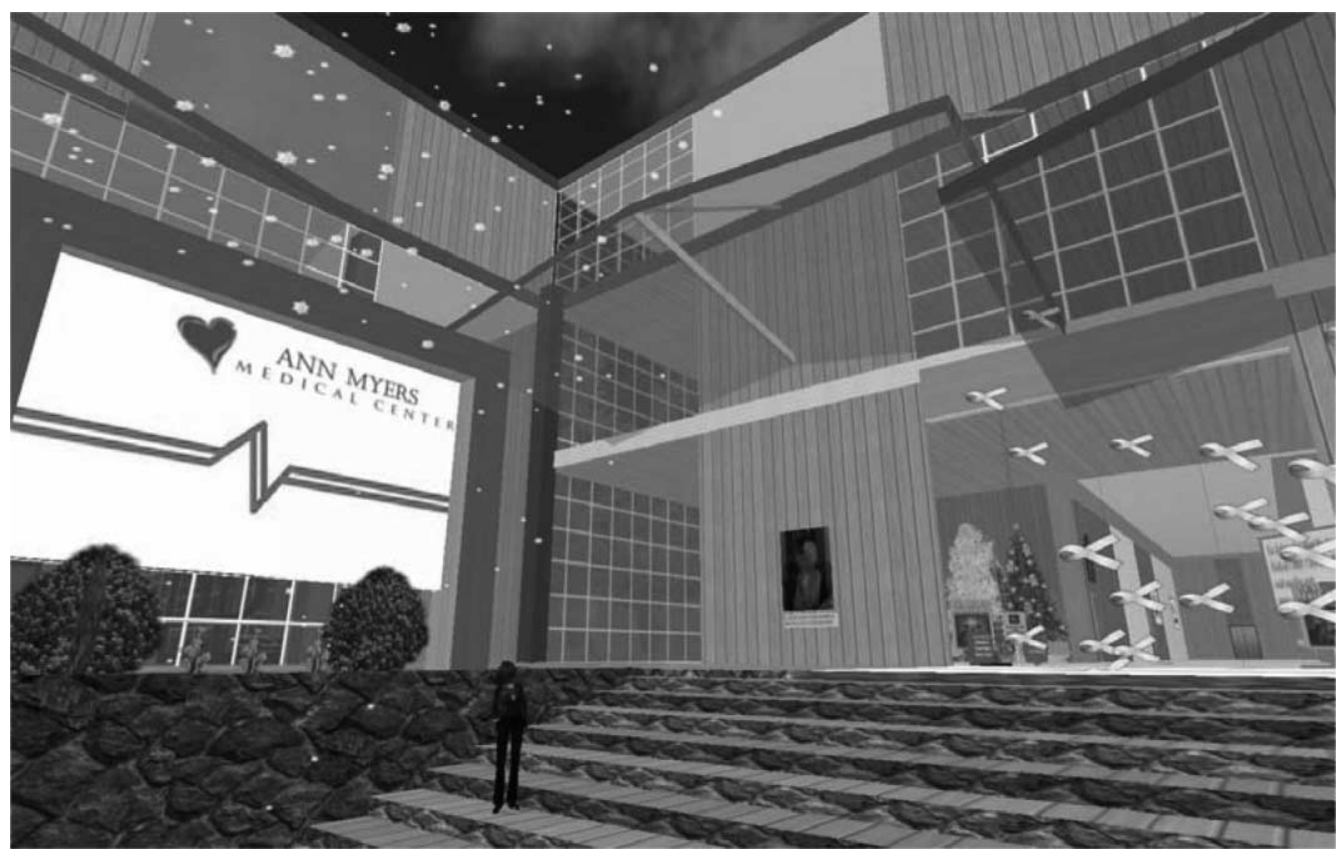

Figure 2. Ann Meyers Medical Center in Second Life.

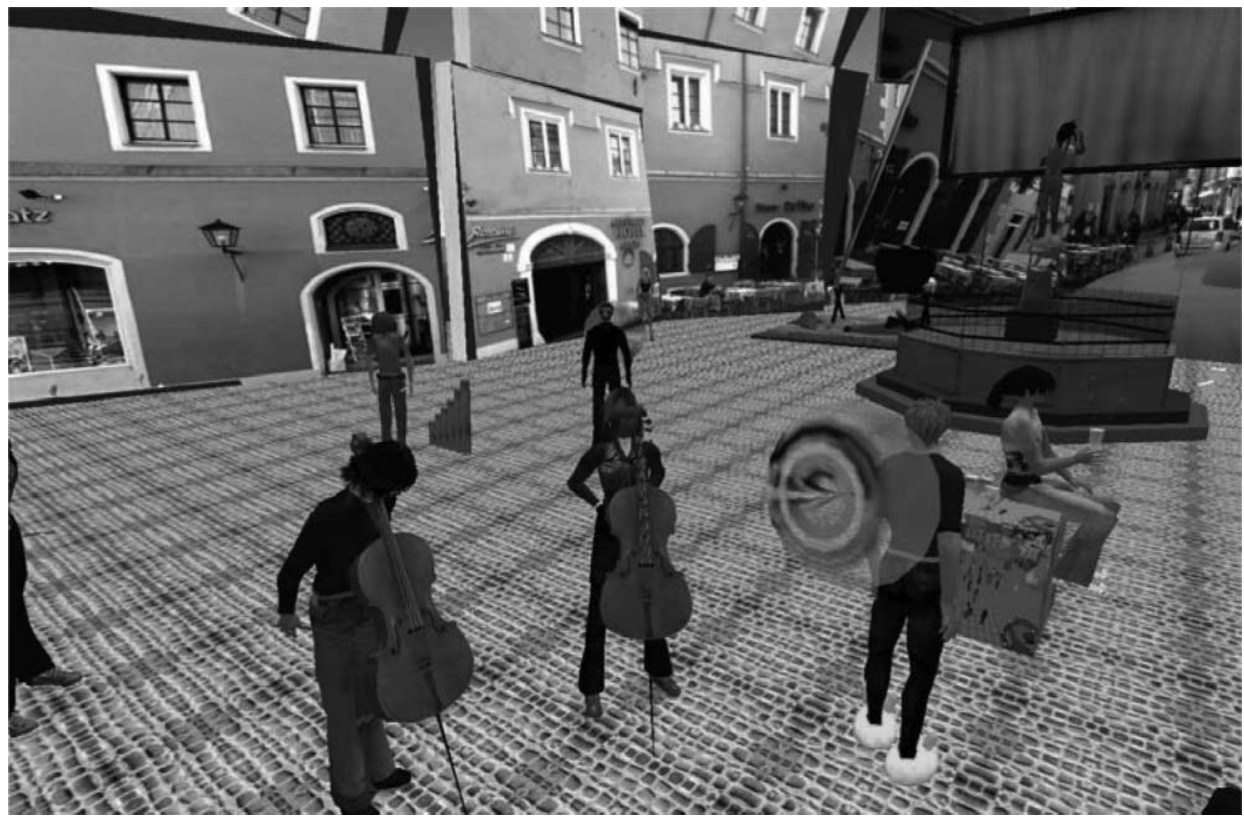

Figure 3. The avatar orchestra metaverse (AOM) in Second Life. 


\section{Project-based pedagogy}

The designer and instructor of the course is a senior lecturer who has offered the graduate seminar in interdisciplinary communication for four years. The course's theoretical underpinnings are grounded in the findings of the 2004 Facilitating Interdisciplinary Research Convocation of the National Academy of Sciences. A top recommendation of the Academy is to have "institutions, project leaders, principal investigators, educators, postdoctoral scholars, and students focused on enhancing communication between researchers" (CFIR, 2005, 190, emphasis added). Therefore, the syllabus for Communicating across disciplinary cultures in Second Life focused on developing mental flexibility and a deep understanding of diverse audiences with different expectations and worldviews. The course featured a project-based learning design requiring students to demonstrate their grasp of communication strategies, reasoning through analogy (e.g. to help build understanding of perspectives from nursing and rhetoric), and building multi-causal explanations (Miller and Mansilla, 2004 ) by completing a semester-long team project ( $20 \%$ of final grade). Adding the SL component provided a 3-D virtual world environment for students to apply, test, repeat, adapt, and improve their use of communication strategies in some ways that are quite simply beyond the reach of a physical classroom. In order to complete course assignments and projects, students had to interact extensively with educational and non-academic participants both in real life and in SL.

In the course, students systematically explored and analyzed in their semester-long "worldview journals" meta-perspectives on different ways humans generate new knowledge in the face of on-going change, disciplinary conflicts, and even risk. With demands for interdisciplinary research and virtual research teams increasing, students had opportunities to discover and practice flexibility of outlook and to enhance their abilities as scientists and scholars to work and learn across disciplines more effectively. The goal of the course was not to discover a single unifying answer, but rather to understand and apply the notion of "communication adaptability" itself. Students in the class were challenged by the question posed by Helen Fox (1994): "Are you ready to imagine knowledge differently?" (p. 136).

This course framework, therefore, lent itself to inclusion in our pilot research study exploring learning in the 3-D virtual world environment of SL. The students formed an interdisciplinary team (Figure 4), and they chose to initiate a collaboration with the Basic Initiative and a group of architecture students to create a virtual presence in SL of two green, sustainable, urban housing designs called the Alley Flats. The BaSiC Initiative is a collaboration of faculty and students from the University of Texas at Austin, School of Architecture (http://www.basicinitiative.org).

Over the semester students took SL "field trips," engaged other communities, worked with architects (Figure 5), and communicated with educators and non-academic participants. Their project culminated with a formal ribbon-cutting ceremony in SL in which the instructor, students, collaborators, and guests from all over the world participated in a virtual presentation and walk-through of the two Alley Flat virtual homes.

Their project became both local and global in that: (1) the two virtual model homes created in SL are physically being built in a low-income neighborhood in Austin, Texas (Figure 6), and (2) the virtual presence of the two homes in SL gives people around the world the opportunity to walk (or fly) through the Alley Flats in SL. The virtual homes are interactive, so visitors can learn about sustainable design features, see architectural drawings, and access the network of collaborating organizations simply by clicking on parts of the models. 


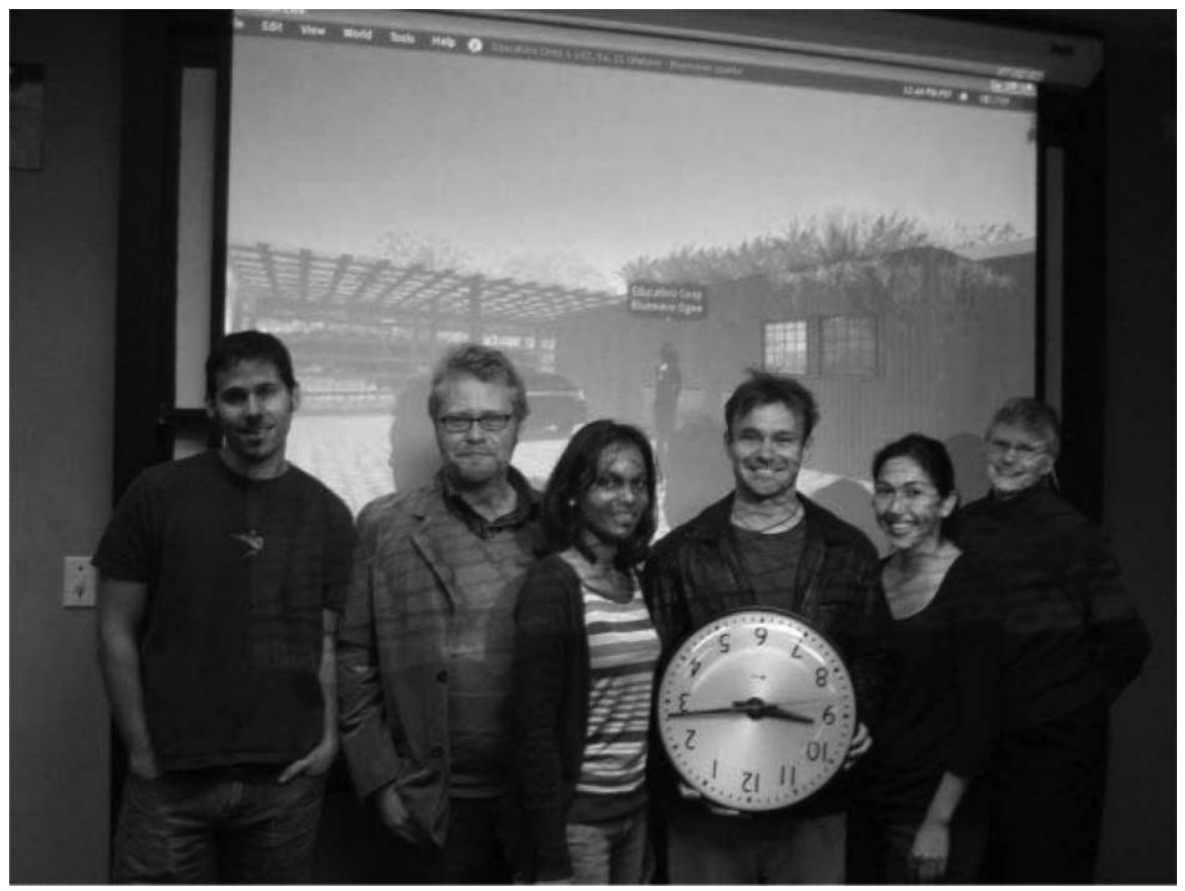

Figure 4. The graduate student interdisciplinary team.

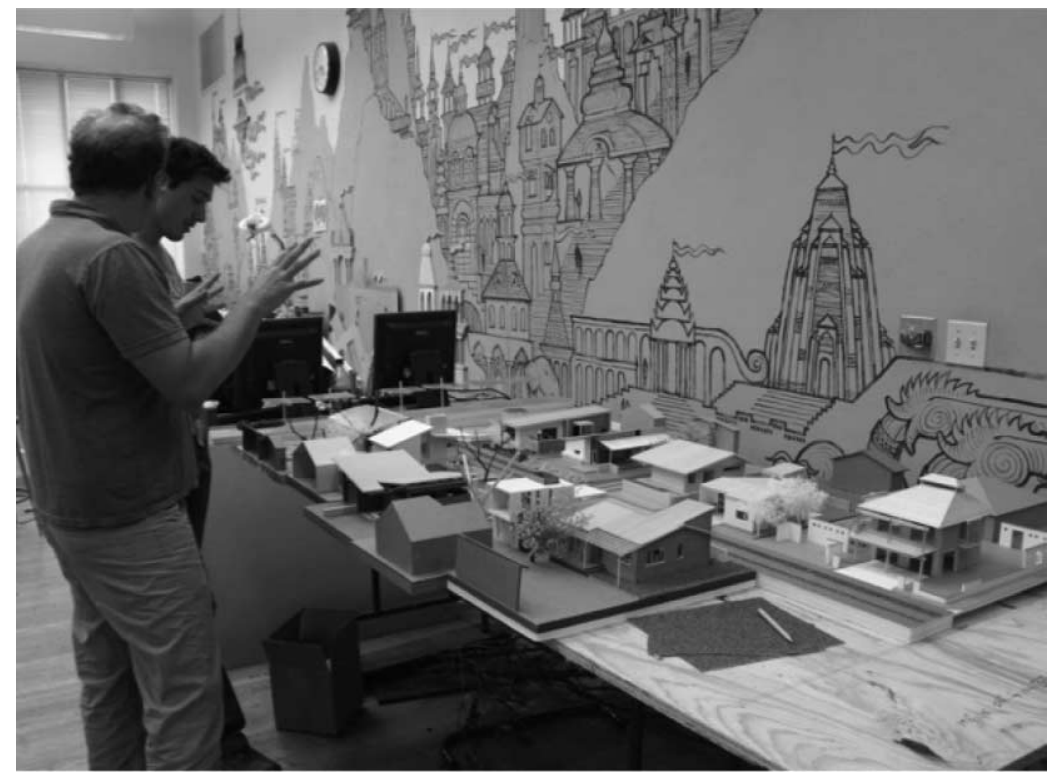

Figure 5. Students working with Alley Flats architects. 


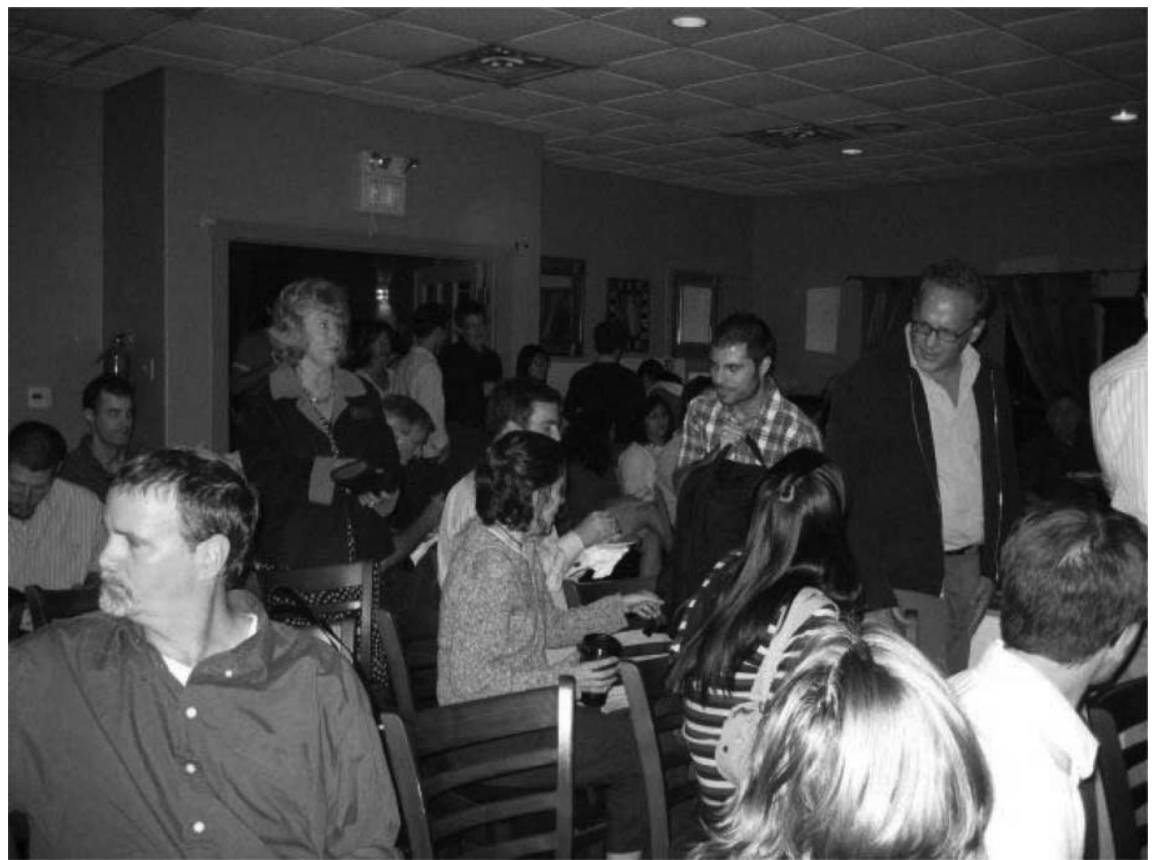

Figure 6. Neighborhood town meeting.

\section{Technical support and training}

In preparation for the class, an inventory of key computer labs on campus was taken to identify labs with SL permanently installed, labs that allowed students to install SL, and labs that prohibited SL from being installed due to administrative restrictions. One of the largest computer labs that was open to all students allowed SL to be installed (although the software was erased immediately after the student logged off). Fortunately, most students were able to use SL on their own laptops.

The students were expected to have completed SL's Orientation Island training prior to the beginning of the semester as a requirement for permission to register. Additionally, students were provided with two, one-hour training sessions and online tutorials to cover basic skills such as managing inventory, customizing avatars, communicating, and exploring SL. In addition, the SL trainer held weekly office hours although these were rarely attended after the first two weeks of class.

\section{Research methodology}

We view assessment as an essential component of SL pilot projects. Data gathered from the instructional settings and students' experiences provide critical information to help us understand how 3-D virtual worlds might foster the achievement of instructional objectives and how such technology might be better employed in specific instructional contexts. Although empirical data are often not collected and analyzed systematically to assess the effects of new technology, assessment was built into our pilot from the earliest stage with the team collaboration in the collection, analysis, and interpretation of the data.

We approached our assessment on two levels: evaluation that helps us understand how to use SL for teaching in general and context-specific research focusing on the nature of 
learning in SL. For the first focus, we used the same survey across different pilot courses, and our online survey addressed six issues of how to use SL for teaching in general:

- Student reactions to the specific SL activity (in terms of enjoyment, relevance to the course content, social interaction, directions);

- Student perceptions of the effects of using SL on their learning and involvement;

- Student attitudes towards the use of SL in a course in general;

- Ease of SL use;

- Student use of SL (how long, what they do);

- The relationship between the preference for games and attitudes towards using SL for a course.

For the second assessment focus, we wanted to understand in more depth the nature of learning within SL in a specific instructional context. Three specific research questions were posed for this course:

(1) What types of learning do students experience when using SL?

(2) Does learning in SL transfer to real life?

(3) Do students perceive SL as instrumental in learning?

We employed various qualitative data collection and analysis methods, including student surveys, content analysis of their worldview journals, a focus group, and analyses of photos and movies (machinima) taken in SL. The student surveys (see Appendix) were administered in paper format and were conducted twice, at the beginning and at the end of the semester. Survey questions addressed students' learning in SL and their attitudes towards the use of SL for instructional settings. The surveys posed parallel questions, the first asking students about their attitudes about learning in SL before they started the course, and the second survey asking about their attitudes after taking the course.

Upon completion of the semester, and after course grades were reported, the students voluntarily submitted their worldview journals for content analysis. The research team used standard content analysis procedures and categorized the journal entries into the following six types of learning events. The categories were based on content analysis and inter-rater reliability training of 10 anonymous sample journal entries identified in student journals from a prior semester that did not include any virtual world components:

(1) Interdisciplinary Worldview Awareness: students identify moments of awareness and/or perspective change regarding their understanding of their own worldviews in terms of interdisciplinary communication such as a previously unrecognized bias towards other disciplines than their own.

(2) Judgment of Others/Tolerance: students identify moments when they realize they were judging another person based on their own worldview assumptions in their life in general (not in terms of interdisciplinary communication).

(3) Worldview Awareness: students identify moments when they realize certain characteristics of their own and/or others' worldviews (but not necessarily in terms of interdisciplinary communication).

(4) Collaboration/Transforming Learning Experiences: students identify collaborations across academic disciplines and describe the communication strategies used. (The fact that students are collaborating suggests that their understanding is transforming into real-life practices.) 
(5) Unexpected Learning: students explicitly identify realizations that were unexpected.

(6) Transfer of SL experiences into Real Life: students identify moments when SL informed real life experiences, such as real life relationships and collaborations, and physical or emotional feelings that were a result of being and working in SL.

Journal entries could be categorized under more than one type of learning event, and they could also be categorized according to two levels of experiential learning:

- Increased awareness of one's own perceptions and cognitive processes (learning event types 1, 2, 3 and some of 5);

- Demonstration of their understanding about the nature of interdisciplinary communication through actual application of communication strategies (learning event types 4 , 6 and some of 5).

Finally, the categorized entry sections could be used to provide concrete examples of various types of the learning incidences (research questions 1 and 2).

Immediately following the final presentation of the students' semester-long team project (the formal ribbon-cutting ceremony in SL), the research team conducted a 90-minute focus group session with seven core questions and numerous follow-up questions. Key questions focused on what students believed they learned because of the SL component, significant learning events in SL, how learning in SL transfer to real life, and whether or not the students observed any shift in their attitudes about learning in SL over the course of the semester.

\section{Preliminary results}

\section{Project results}

In the past, students presented the results of their semester-long projects during a straightforward 15-minute PowerPoint presentation in the classroom. However, in the SL pilot course that was the focus of this study, the five-member student team demonstrated their understanding and application of interdisciplinary strategies by creating something that has never existed before and that could not have existed within the brick-and-mortar boundaries of their classroom: the Alley Flats virtual presence in SL (Figure 7).

The team's original plan was within the scope of learning activity anticipated by the instructor. However, the global nature of the SL virtual world itself had a powerful impact on the students' plan, and with the team's decision to "go public" and to include a virtual ribbon-cutting ceremony, their project exceeded expectations. That is, the affordances of the 3-D virtual world learning environment led to experiential activities that not only helped to achieve learning outcomes but also to surpass course objectives. The students' decision to host a formal virtual ceremony also shifted the instructor's role because going public in SL meant that UT-Austin was represented in an unprecedented public, albeit virtual, space. The student team forged collaborations with volunteer expert builders in SL, members of the Educators Coop, who used the actual architectural drawings (Figure 8) to render the two virtual houses (Figure 9). Team members worked with the architects in both the real world in Austin and at the virtual site in SL (located on the Educators Coop Island). 


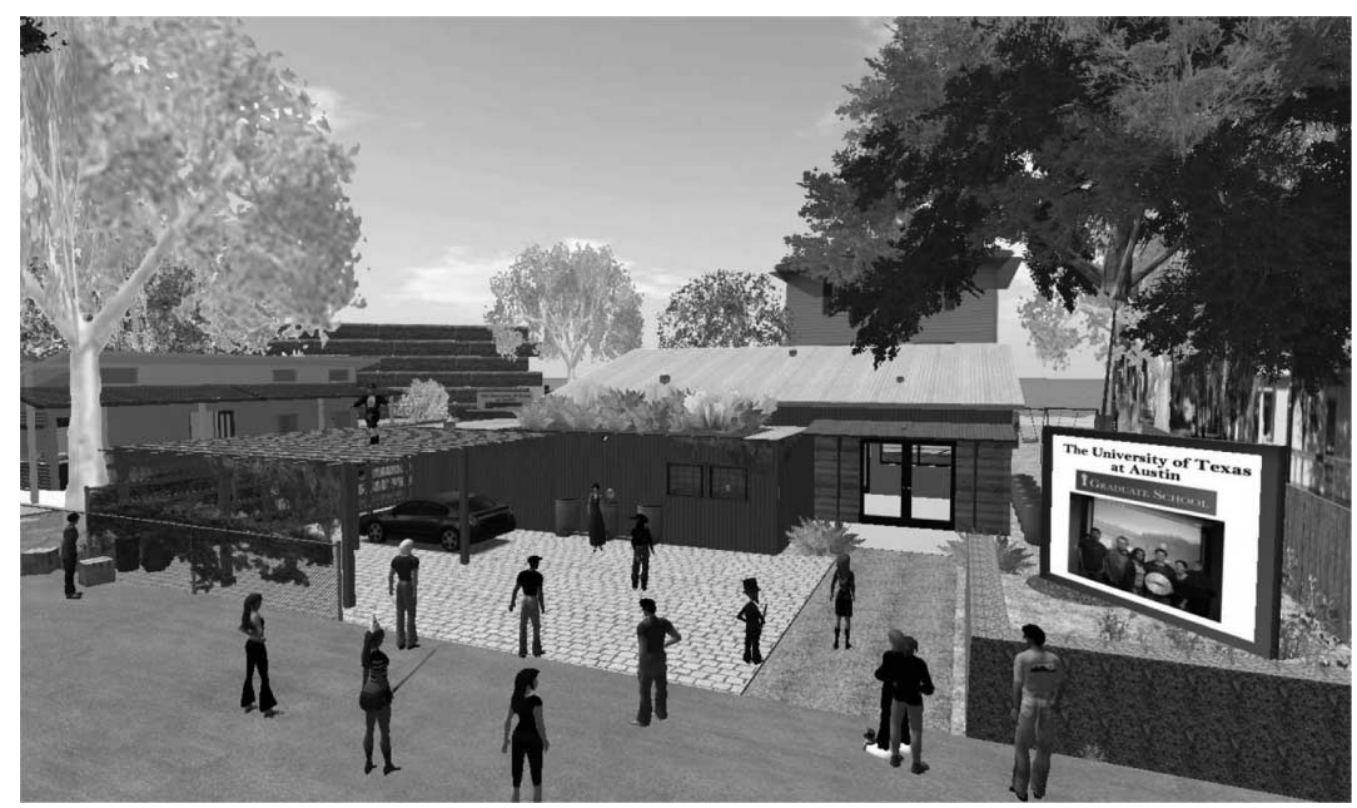

Figure 7. The Alley Flats virtual presence in Second Life.

\section{Preliminary survey results focused on student perceptions of the effects of using $S L$}

All students responded to the first survey and four out of five (80\%) students responded to the second survey. Although other data are still being analyzed, it is important for us to be careful in interpreting these results and not to over-generalize the findings to other instructional contexts because of the small number of participants.

In general, students expected that their engagements and learning would increase with SL $(80 \%)$, before the project. At the end of semester, students strongly supported the

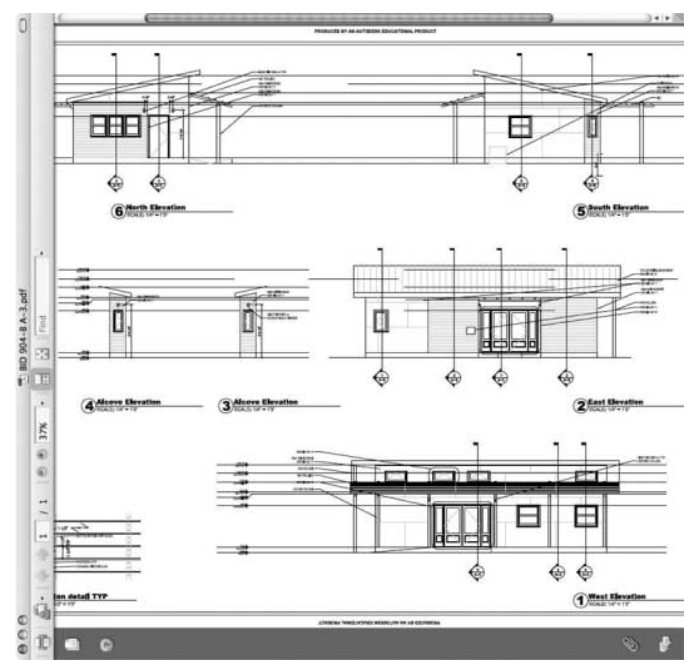

Figure 8. Architectural drawings of Allev Flat. 


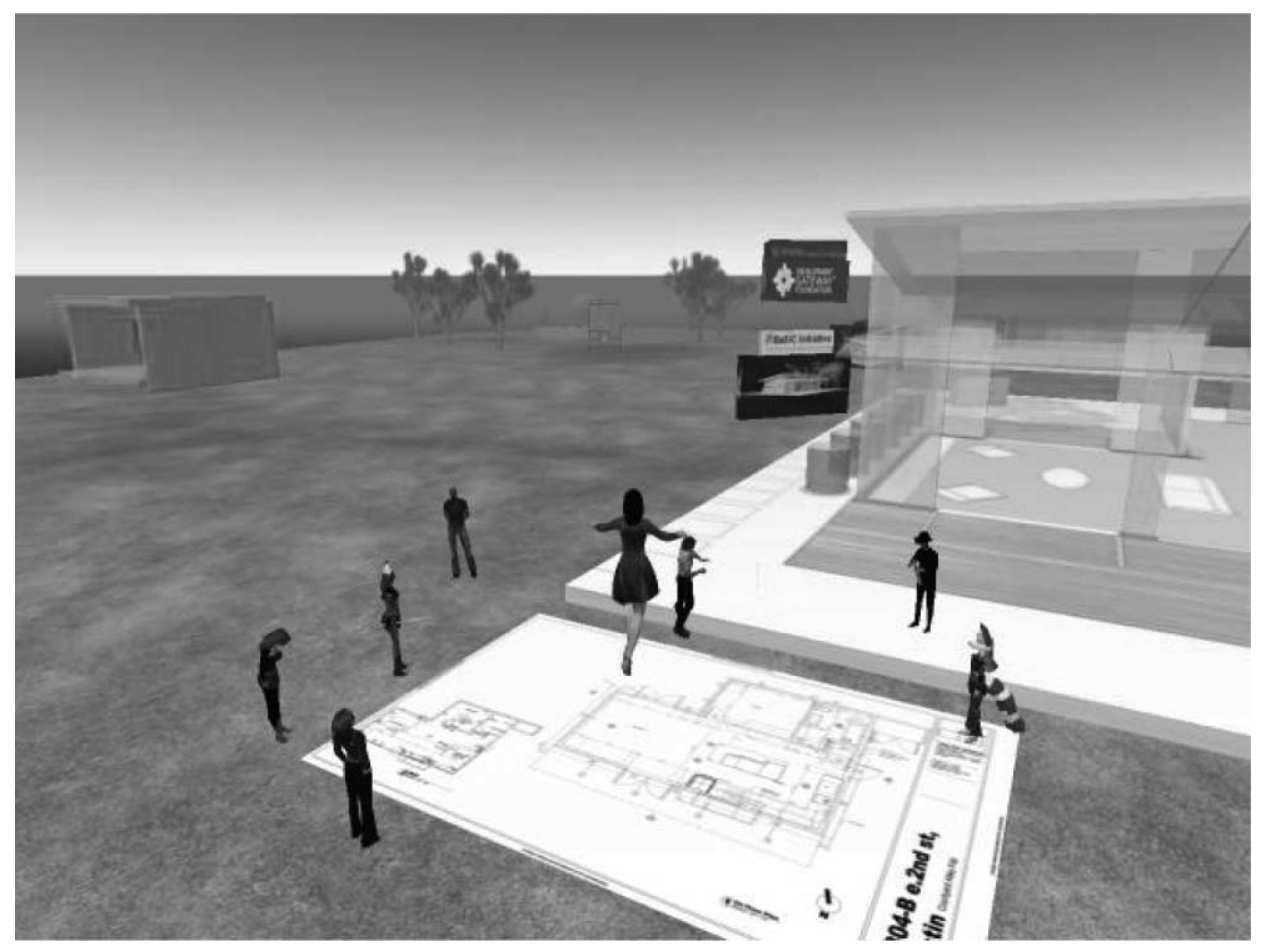

Figure 9. Using architectural drawings in Second Life to build virtual green homes.

effectiveness of instructional use of SL. Most of the respondents agreed that it was a good idea $(100 \%)$ and enjoyable $(100 \%)$ to use SL in this course, and that SL was instrumental in increasing their engagement in the course $(100 \%)$, increasing learning $(100 \%)$, and expanding their own research ideas (75\%). Students also reported that the team project was enjoyable (100\%) and engaging (100\%), and provided good learning experiences $(75 \%)$. Moreover, all students agreed that their desire to go into SL on their own increased over the course of the semester, further support of their positive reactions to the use of SL.

However, in some respects, students' responses were not all positive. In terms of facilitating communication and collaboration among students, student perception of SL was negative or mixed before the semester ( $40 \%$ disagree to both) and those feelings persisted until the end of the semester ( $75 \%$ disagree and $25 \%$ disagree respectively). Also, only $50 \%$ of the respondents agreed that the team project in SL was relevant to the course content. Reasons for these negative/mixed responses are likely to emerge from the focus group data and student journals. As for the ease of use, most (75\%) disagreed that SL was easy to use, and all commented that they would like to have more training on how to use SL, in particular on building objects. All agreed that SL is worth using for some courses, even when there are some software difficulties.

In summary, the survey results indicate that the use of SL using a project-based experiential instructional design that exploits the affordances of a 3-D virtual environment can substantially enhance the quality and experiences of student learning, as suggested by the literature (Amichai-Hamburger and McKenna, 2006; Soukup, 2004). Furthermore, our survey results support the research findings of Steinkuehler and Williams (2006) that interacting within virtual worlds can expose people to a diversity of worldviews and can help 
them to build a sense of community through the development of virtual social relationships. Additionally, these survey results align with prior research showing that motivation and learning can increase when working with other agents in a virtual environment due to their perceived social relationship (Atkinson et al., 2005; Kim and Baylor, 2006; Mayer et al., 2003; Moreno et al., 2001).

However, the survey results also indicate some areas for improvement in future research and application. More explicit integration of SL course components into an overall course description would possibly lead to better student understanding. In terms of the ease of using SL, substantial improvement is needed to facilitate additional early training and acclimation to the virtual social space. Analysis of the other data will provide us more detailed understanding of the process and nature of student learning in SL and of evermore specific and subtle challenges facing learners, instructors and researchers working in 3-D virtual world environments. Finally, one can view a video characterization of the student team's Alley Flats Initiative in SL and hear the students characterization of their experiences in their own voices by following the following link: http://www.youtube.com/ watch?v=jAJAp_2bcX0\&eurl=http:/www.newmornings.org/.

\section{Conclusion}

Given that virtual worlds are expected to have a large impact on teaching and learning in the very near future, in this article we presented a concrete case study and we recommend a pragmatic and reasonable method for new teachers and learners to "take the plunge." Although preliminary in nature, our findings suggest the effectiveness of an integrated threefold approach: project-based pedagogy, technical training and support, and assessment. We encourage educators to utilize the unique affordances of SL by creating instructional designs that give students the opportunity to work on real-world projects while exploring and communicating across geographic boundaries. Furthermore, because there is still so much to learn about this emerging 3-D virtual world environment, we also recommend a systematic team approach for educators. It is critical to integrate well elaborated technical training and support as well as to measure the impact of newly employed technology on learning. Such knowledge helps researchers and educators plan for future instructional applications of virtual worlds and specifically SL. More research is needed to understand how project-based collaborative activity supported by the pedagogy, training, and assessment trio may apply to other instructional contexts using SL and including, for example, undergraduate and high school courses and shorter term student projects. We are currently studying key factors for defining the parameters of learning activities across a range of classes in SL, including their duration, their frequency, their objectives, and the nature of the activities themselves.

\section{References}

Akrich, M. (1992). The description of technical objects. In W. Bijker and J. Law (Eds.), Shaping technology/building society: Studies in sociotechnical change (pp. 205-224). Cambridge: MIT Press.

Amichai-Hamburger, Y., \& McKenna, K. (2006). The contact hypothesis reconsidered: Interacting via the Internet. Journal of Computer-Mediated Communication, 11(3), 825-843.

Atkinson, R.K., Mayer, R., \& Merrill, M. (2005). Fostering social agency in multimedia learning: Examining the impact of an animated agent's voice. Contemporary Educational Psychology, 30(1), 117-139.

Bateson, M.C. (1993). Joint performance across cultures: Improvisation in a Persian garden. Text and Performance Quarterly, 13, 113-121. 
Brouchoud, J. (2006). The Arch blog. Retrieved December 15, 2007, from http://archsl.wordpress.com/ about/

Craig, E. (2007, June). Meta-perspectives on the metaverse: A blogsphere debate on the significance of Second Life. Paper presented at ED-MEDIA World Conference on Educational Multimedia, Hypermedia \& Telecommunications, Vancouver, Canada.

Committee on Facilitating Interdisciplinary Research (CFIR). (2005). Facilitating Interdisciplinary Research. Washington, DC: National Academies Press. Retrieved December 20, 2007, from http://www.nap.edu/catalog.php?record_id=11153

Dede, C., Clarke, J., Ketelhut, D., Nelson, B., \& Bowman, C. (2005, April). Fostering motivation, learning, and transfer in multi-user virtual environments. Paper presented at the American Educational Research Association Conference, Montreal, Canada.

FitzGerald, S. (2007). Virtual worlds: What are they and why do educators need to pay attention to them? Paper presented at E-learning Networks June Online Event. Retrieved July 13, 2007, from http://seanfitz.wikispaces.com/virtualworldsenetworks07

Fox, H. (1994). Listening to the world: Cultural issues in academic writing. Urbana, IL: National Council of Teachers of English.

Gartner, Inc. (2007). Gartner says 80 percent of active Internet users will have a "Second Life" in the virtual world by the end of 2011. Business Wire, April 24. Retrieved December 15, 2007, from http://www.businesswire.com/portal/site/google/index.jsp?ndmViewId=news_view\&news $\mathrm{Id}=20070424006287 \&$ newsLang $=$ en

Gee, J.P. (2003). What video games have to teach us about learning and literacy. New York: Palgrave Macmillan.

Kim, Y., \& Baylor, A. (2006). A social-cognitive framework for pedagogical agents as learning companions. Educational Technology Research \& Development 54(6), 569-590.

Kirriemuir, J., \& McFarlane, A. (2003). Literature review in games and learning. Retrieved January 5, 2008, from http://www.futurelab.org.uk/resources/documents/lit_reviews/Games_Review.pdf

Lamb, G.M. (2006). Real learning in a virtual world. The Christian Science Monitor, October 5. Retrieved January 3, 2007, from http://www.csmonitor.com/2006/1005/p13s02-legn.html

Mayer, R.E., Sobko, K., \& Mautone, P. (2003). Social cues in multimedia learning: Role of speaker's voice. Journal of Educational Psychology, 95, 419-425.

Mayrath, M.C., Sanchez, J., Traphagan, T., Heikes, J., \& Trivedi, A. (2007, June). Using Second Life in an English course: Designing class activities to address learning objectives. Paper presented at ED-MEDIA World Conference on Educational Multimedia, Hypermedia \& Telecommunications, Vancouver, Canada.

McGee, P. (2007, June). Extreme learning in a virtual (world) learning environment: Who needs pedagogy anyway? Paper presented at ED-MEDIA World Conference on Educational Multimedia, Hypermedia \& Telecommunications, Vancouver, Canada.

Miller, M., \& Mansilla, V. (2004). Thinking across perspectives and disciplines. Good Work Project Report Series, no. 27. \#GW-2027. Cambridge, MA: Harvard Project Zero. Retrieved December 20, 2007, from http://pzweb.harvard.edu/eBookstore/PDFs/GoodWork27.pdf

Moreno, R., Mayerm, R., Spires, H., \& Lester, J. (2001). The case for social agency in computerbased teaching: Do students learn more deeply when they interact with animated pedagogical agents? Cognition and Instruction, 19(2), 177-213.

Prensky, M. (2006). Don't bother me, Mom, I'm learning!: How computer and video games are preparing your kids for 21st century success and how you can help! St. Paul: Paragon House.

Sanchez, J. (2007, June). A sociotechnical systems analysis of Second Life in an undergraduate English course. Paper presented at ED-MEDIA World Conference on Educational Multimedia, Hypermedia \& Telecommunications, Vancouver, Canada.

Soukup, C. (2004). Multimedia performance in a computer-mediated community: Communication as a virtual drama. Journal of Computer-Mediated Communication, 9(4). Retrieved July 24, 2007, from http://jcmc.indiana.edu/vol9/issue4/soukup.html

Steinkuehler, C., \& Williams, D. (2006). Where everybody knows your (screen) name: Online games as "third places." Journal of Computer-Mediated Communication, 11(4). Retrieved July 24, 2007, from http://jcmc.indiana.edu/vol11/issue4/steinkuehler.html

Taussig, M. (1993). Mimesis and alterity: A particular history of the senses. New York: Routledge.

The New Media Consortium and the EDUCAUSE Learning Initiative. (2007). The Horizon Report. Retrieved March 20, 2007, from http://www.nmc.org/horizon/2007/report 


\section{Appendix: Student surveys}

The research questions to address in this study:

(1) What types of learning do students experience often in Second Life?

(2) Does learning in Second Life transfer to real life?

(3) Do students perceive Second Life as instrumental in learning?

\section{Survey method}

Paper surveys are conducted twice, at the beginning and the end of the semester. Most of the questions in the first and second surveys are parallel questions. Survey questions address students' learning in SL and their attitudes towards the use of SL for instructional settings.

\section{First survey questions}

This survey was developed only for the Interdisciplinary Communication course.

Part I: How do students expect the use of Second Life to affect student learning?

1. My engagement in this course will increase because of Second Life.

\begin{tabular}{|c|c|c|c|c|}
\hline Strongly Disagree & Disagree & Neutral & Agree & Strongly Agree \\
\hline
\end{tabular}

2. My learning in this course will increase because of Second Life.

\begin{tabular}{|l|l|l|l|l|}
\hline Strongly Disagree & Disagree & Neutral & Agree & Strongly Agree \\
\hline
\end{tabular}

3. My ideas for my own research will expand because of Second Life.

\begin{tabular}{|l|l|l|l|l|}
\hline Strongly Disagree & Disagree & Neutral & Agree & Strongly Agree \\
\hline
\end{tabular}

4. Please describe what you expect to learn because of Second Life. (Open-ended Question)

Part II: How do students feel about using Second Life in the course?

5. I will enjoy using Second Life in this course.

\begin{tabular}{|l|l|l|l|l|}
\hline Strongly Disagree & Disagree & Neutral & Agree & Strongly Agree \\
\hline
\end{tabular}

6. It is a good idea to use Second Life in this course.

\begin{tabular}{|l|l|l|l|l|}
\hline Strongly Disagree & Disagree & Neutral & Agree & Strongly Agree \\
\hline
\end{tabular}

7. The use of Second Life will help me communicate with my fellow students.

\begin{tabular}{|c|c|c|c|c|}
\hline Strongly Disagree & Disagree & Neutral & Agree & Strongly Agree \\
\hline
\end{tabular}

8. The use of Second Life will help me collaborate with my fellow students.

\begin{tabular}{|l|l|l|l|l|}
\hline Strongly Disagree & Disagree & Neutral & Agree & Strongly Agree \\
\hline
\end{tabular}


9. Please provide any additional comments about the use of Second Life in this course. (Open-ended Question)

\section{Second survey questions}

This survey includes both questions that are specific to the Interdisciplinary Communication course, and questions that are commonly asked in all the SL pilot courses.

Thinking of the situations where you did not have substantial technical difficulties (e.g. Second Life is lagging), please answer the following questions about learning with Second Life in this course.

Part I: How did the use of Second Life affect student learning?

1. My engagement in this course increased because of Second Life.

\begin{tabular}{|c|c|c|c|c|}
\hline Strongly Disagree & Disagree & Neutral & Agree & Strongly Agree \\
\hline
\end{tabular}

2. My learning in this course increased because of Second Life.

\begin{tabular}{|l|l|l|l|l|}
\hline Strongly Disagree & Disagree & Neutral & Agree & Strongly Agree \\
\hline
\end{tabular}

3. My ideas for my own research expanded because of Second Life.

\begin{tabular}{|l|l|l|l|l|}
\hline Strongly Disagree & Disagree & Neutral & Agree & Strongly Agree \\
\hline
\end{tabular}

4. Please describe what you learned because of Second Life in this course. (Open-ended Question)

5. Please describe the most significant learning event you experienced because of Second Life in this course. (Open-ended question)

Part II: How do students feel about using Second Life in the course?

6. I enjoyed using Second Life in this course.

\begin{tabular}{|l|l|l|l|l|}
\hline Strongly Disagree & Disagree & Neutral & Agree & Strongly Agree \\
\hline
\end{tabular}

7. It is a good idea to use Second Life in this course.

\begin{tabular}{|c|c|c|c|c|}
\hline Strongly Disagree & Disagree & Neutral & Agree & Strongly Agree \\
\hline
\end{tabular}

8. The use of Second Life helped me communicate with my fellow students.

\begin{tabular}{|l|l|l|l|l|}
\hline Strongly Disagree & Disagree & Neutral & Agree & Strongly Agree \\
\hline
\end{tabular}

9. The use of Second Life helped me collaborate with my fellow students.

\begin{tabular}{|c|c|c|c|c|}
\hline Strongly Disagree & Disagree & Neutral & Agree & Strongly Agree \\
\hline
\end{tabular}

10. If there is another opportunity to take a course that uses Second Life, I will take it.

\begin{tabular}{|l|l|l|l|l|}
\hline Strongly Disagree & Disagree & Neutral & Agree & Strongly Agree \\
\hline
\end{tabular}

11. Please provide any additional comments about the use of Second Life in this course. 
Part III: How did the students like the Second Life activity?

12. I enjoyed the Expert Guest Faculty sessions from Second Life.

\begin{tabular}{|l|l|l|l|l|}
\hline Strongly Disagree & Disagree & Neutral & Agree & Strongly Agree \\
\hline
\end{tabular}

13. I found the Expert Guest Faculty sessions from Second Life to be engaging.

\begin{tabular}{|c|c|c|c|c|}
\hline Strongly Disagree & Disagree & Neutral & Agree & Strongly Agree \\
\hline
\end{tabular}

14. I found Expert Guest Faculty sessions from Second Life to be good learning experiences for this class.

\begin{tabular}{|c|c|c|c|c|}
\hline Strongly Disagree & Disagree & Neutral & Agree & Strongly Agree \\
\hline
\end{tabular}

15. I thought the Expert Guest Faculty sessions from Second Life were relevant to the course content.

\begin{tabular}{|c|c|c|c|c|}
\hline Strongly Disagree & Disagree & Neutral & Agree & Strongly Agree \\
\hline
\end{tabular}

16. I liked the social interaction in the Expert Guest Faculty sessions from Second Life.

\begin{tabular}{|c|c|c|c|c|}
\hline Strongly Disagree & Disagree & Neutral & Agree & Strongly Agree \\
\hline
\end{tabular}

17. Please provide any additional comments on the Expert Guest Faculty sessions from Second Life. (Open-ended question)

18. The Expert Guest Faculty sessions from Second Life would have been better if we had done it in person instead of in Second Life.

\begin{tabular}{|c|c|c|c|c|}
\hline Strongly Disagree & Disagree & Neutral & Agree & Strongly Agree \\
\hline
\end{tabular}

19. I was able to participate and express my ideas during the Expert Guest Faculty sessions from Second Life.

\begin{tabular}{|l|l|l|l|l|}
\hline Strongly Disagree & Disagree & Neutral & Agree & Strongly Agree \\
\hline
\end{tabular}

20. I enjoyed the Interdisciplinary Strategies Group Project \& Presentation from Second Life.

\begin{tabular}{|c|c|c|c|c|}
\hline Strongly Disagree & Disagree & Neutral & Agree & Strongly Agree \\
\hline
\end{tabular}

21. I found the Interdisciplinary Strategies Group Project \& Presentation to be engaging because we used Second Life.

\begin{tabular}{|c|c|c|c|c|}
\hline Strongly Disagree & Disagree & Neutral & Agree & Strongly Agree \\
\hline
\end{tabular}

22. I found the Interdisciplinary Strategies Group Project \& Presentation to be good learning experiences for this class because we used Second Life.

\begin{tabular}{|l|c|c|c|c|} 
Strongly Disagree & Disagree & Neutral & Agree & Strongly Agree \\
\hline
\end{tabular}


23. I thought the part of the Interdisciplinary Strategies Group Project \& Presentation that involved using Second Life was relevant to the course content.

\begin{tabular}{|l|l|l|l|l|}
\hline Strongly Disagree & Disagree & Neutral & Agree & Strongly Agree \\
\hline
\end{tabular}

24. I liked the Second Life part of the social interaction in the Interdisciplinary Strategies Group Project \& Presentation.

\begin{tabular}{|l|l|l|l|l|}
\hline Strongly Disagree & Disagree & Neutral & Agree & Strongly Agree \\
\hline
\end{tabular}

25. I found the part of the Interdisciplinary Strategies Group Project \& Presentation that involved using Second Life to be challenging.

\begin{tabular}{|c|c|c|c|c|}
\hline Strongly Disagree & Disagree & Neutral & Agree & Strongly Agree \\
\hline
\end{tabular}

26. I was able to learn enough Second Life skills to successfully complete Interdisciplinary Strategies Group Project \& Presentation.

\begin{tabular}{|c|c|c|c|c|}
\hline Strongly Disagree & Disagree & Neutral & Agree & Strongly Agree \\
\hline
\end{tabular}

27. Please provide any additional comments on the Interdisciplinary Strategies Group Project \& Presentation that involved the use of Second Life. (Open-ended question)

28. I was able to fully express my ideas during the Interdisciplinary Strategies Group Project \& Presentation that involved using Second Life.

\begin{tabular}{|l|l|l|l|l|}
\hline Strongly Disagree & Disagree & Neutral & Agree & Strongly Agree \\
\hline
\end{tabular}

Part IV: Is the Second Life interface easy to use?

29. In general, Second Life is easy to use.

\begin{tabular}{|c|c|c|c|c|}
\hline Strongly Disagree & Disagree & Neutral & Agree & Strongly Agree \\
\hline
\end{tabular}

30. Moving my avatar around in Second Life is easy.

\begin{tabular}{|c|c|c|c|c|}
\hline Strongly Disagree & Disagree & Neutral & Agree & Strongly Agree \\
\hline
\end{tabular}

31. Changing my avatar in Second Life is easy.

\begin{tabular}{|c|c|c|c|c|}
\hline Strongly Disagree & Disagree & Neutral & Agree & Strongly Agree \\
\hline
\end{tabular}

32. Communicating with others in Second Life by Chat or instant messages is easy.

\begin{tabular}{|l|l|l|l|l|}
\hline Strongly Disagree & Disagree & Neutral & Agree & Strongly Agree \\
\hline
\end{tabular}

33. If you have had difficulties in Second Life, please describe them. (Open-ended question)

a. Linden Lab's problems (e.g. glitches, lags, updates, and crashes)

b. Other problems 
34. Should there be training for beginning SL users or should the student have to figure out how to use SL on their own? If so, what level of training is needed? (Open-ended question)

35. Please provide any additional comments about the ease of use of Second Life. (Openended question)

Part V: How (how long, with which computer, what they do [anything beyond their assignments?]) do students use Second Life?

36. Over the course of the semester, the amount of time I spent in Second Life increased.

\begin{tabular}{|c|c|c|c|c|}
\hline Strongly Disagree & Disagree & Neutral & Agree & Strongly Agree \\
\hline
\end{tabular}

37. Over the course of the semester, my desire to go into Second Life on my own increased.

\begin{tabular}{|c|c|c|c|c|}
\hline Strongly Disagree & Disagree & Neutral & Agree & Strongly Agree \\
\hline
\end{tabular}

38. Even with all the technological difficulties (such as glitches, lags, frequent updates, and crashes), Second Life is worth using for some courses.

\begin{tabular}{|c|c|c|c|c|}
\hline Strongly Disagree & Disagree & Neutral & Agree & Strongly Agree \\
\hline
\end{tabular}

39. On average, how often do you access Second Life in a week? (less than once, 1-3 times, 4-7 times, more than 7 times)

40. On average, how much time do you spend in Second Life in a week? (do not use, less than an hour, 1-2 hours, 3-5 hours, 6-10 hours, 11-15 hours, more than 15 hours)

41. Which computer did you mainly use to access Second Life? (personal computer, computer at lab, others' computer)

42. Please describe what you do in Second Life beyond your assignments. (open-ended question)

Part VI: What is the relationship between the preference for games and attitudes towards using Second Life for a course?

43. I like being in a virtual world such as Second Life or There.

\begin{tabular}{|l|l|l|l|l|l|}
\hline Never Done It & Strongly Disagree & Disagree & Neutral & Agree & Strongly Agree \\
\hline
\end{tabular}

44. I like playing console games such as PlayStation games or XBox games.

\begin{tabular}{|l|l|l|l|l|l|}
\hline Never Done It & Strongly Disagree & Disagree & Neutral & Agree & Strongly Agree \\
\hline
\end{tabular}

45. I like playing computer games (not including virtual worlds or console games) such as World of Warcraft (WoW) or Everquest)

\begin{tabular}{|l|l|l|l|l|l|}
\hline Never Done It & Strongly Disagree & Disagree & Neutral & Agree & Strongly Agree \\
\hline
\end{tabular}

46. I like it when my instructor uses computer games (not including virtual worlds such as Second Life) in class.

\begin{tabular}{|l|l|l|l|l|l|}
\hline Never Done It & Strongly Disagree & Disagree & Neutral & Agree & Strongly Agree \\
\hline
\end{tabular}




\section{Part VII Comments}

47. Please provide any suggestions for using Second Life to enhance learning in any courses in the future. (Open-ended question)

48. Please provide any additional information about how you feel about Second Life. (Open-ended question) 
Copyright of Educational Media International is the property of Routledge and its content may not be copied or emailed to multiple sites or posted to a listserv without the copyright holder's express written permission. However, users may print, download, or email articles for individual use. 